\title{
Globalisation, entrepreneurship and regional environment
}

\author{
João Leitão* \\ University of Beira Interior, Technical University of Lisbon, IN+ \\ Convento de Santo António 6201-001 Covilhã, Portugal \\ E-mail: jleitao@ubi.pt \\ *Corresponding author
}

\section{Frank Lasch}

GSCM-Montpellier Business School,

2300 Avenue des Moulins 34185 Montpellier Cedex 4, France

E-mail: f.lasch@supco-montpellier.fr

\section{Roy Thurik}

Erasmus University Rotterdam, P.O. Box 1738, 3000 DR Rotterdam, the Netherlands

E-mail: thurik@ese.eur.nl

\begin{abstract}
Entrepreneurship has been a strategic driver in facilitating the adjustment to technological change and supporting competitiveness in terms of place. Only two decades ago the conventional wisdom predicted that globalisation would destroy the region as a meaningful unit of economic analysis. Yet the obsession of policy-makers around the globe to "create the next Silicon Valley' revealed the increased importance of geographic proximity and regional agglomerations as well as of the role of SMEs and entrepreneurial activity. This article explains the relation between entrepreneurship and space which emerged after the advent of the information and communication technology revolution and the resulting wave of globalisation. But the study of strategic management of regions still needs to address a number of methodological issues. Contrasting results and methodological issues affect entrepreneurship research in this field, many questions by economic actors are unanswered and the valorisation of results for practise remains complex.

The 2008 RENT XXII conference held at the University of Beira Interior in Covilhã, Portugal, invited international scholars to discuss on the topic of 'Entrepreneurship as an engine of regional development'. This article opens a special issue based on the best papers presented at the conference, resumes the state of the field and opens directions for future research.
\end{abstract}

Keywords: entrepreneurship; regional environment; globalisation; proximity; space; entrepreneurship research; ICT.

Reference to this paper should be made as follows: Leitão, J., Lasch, F. and Thurik, R. (2011) 'Globalisation, entrepreneurship and regional environment', Int. J. Entrepreneurship and Small Business, Vol. 12, No. 2, pp.129-138.

Biographical notes: João Leitão is the Head of Management and Administration at the University of Beira Interior (UBI) and an Invited Coordinator Professor at the Polytechnic Institute of Portalegre, Portugal. $\mathrm{He}$ holds a PhD in Economics (2004: UBI), specialising in Market Dynamics and 
Entrepreneurial Pricing. He is a Research Fellow of the Center for Innovation, Technology and Policy Research, Technical University of Lisbon, IN+. He is also an External Research Affiliate at the X-ENT group of the Max Planck Institute of Economics, Jena, Germany. He is also a member of the Board of Directors of the European Council for Small Business and Entrepreneurship Policy Area. His main topics of research are macro-determinants of technological entrepreneurship, entrepreneurial marketing, entrepreneurial behaviour and management of SMEs.

Frank Lasch is an Associate Professor at GSCM-Montpellier Business School, France (Groupe Sup de Co Montpellier). He completed his bi-national PhD in Economic Geography (2002: University of Regensburg, Germany and University of Montpellier III, France) and received his certificate for the supervision of doctoral research (Habilitation) in Management Science (University of Montpellier I) in 2007. His main topics of research are the relationship between entrepreneurship and the regional environment, start-up survival and growth, and entrepreneurship in the ICT sector. He is currently the Dean of Research at GSCM.

Roy Thurik is a Professor of Economics and Entrepreneurship at Erasmus University Rotterdam and Professor of Entrepreneurship at the Free University in Amsterdam. He is also a Scientific Advisor at EIM Business and Policy Research (a Panteia company) in Zoetermeer, the Netherlands, the largest private small business research institute in the world. He is a Research Professor of Entrepreneurship, Growth and Public Policy at the Max-Planck-Institut für Ökonomik (Max Planck Institute of Economics) in Jena, Germany. He is a Research Fellow at two renowned Dutch research schools: the Tinbergen Institute for Economic Sciences and the Erasmus Research Institute for Management. His research focuses on the role of small firms in markets, the role of business owners in firms, industrial organisation and policy, nascent entrepreneurship and the consequences and causes of entrepreneurship in economies.

\section{Introduction}

On 20 and 21 November 2008, the RENT XXII Conference was hosted by the University of Beira Interior, Covilhã, Portugal, on behalf of the European Council for Small Business (ECSB) and with the support of the European Institute for Advanced Studies in Management (EIASM). The RENT Conference has become the leading entrepreneurship research conference in Europe, where senior and junior researchers on entrepreneurship have the opportunity to discuss their latest research findings in an internationally recognised scientific forum.

This special issue represents a selection of the best papers from the 137 presented at the RENT XXII Conference held at the University of Beira Interior in Covilhã, Portugal. Although varied in terms of the topics covered, all of the selected papers contribute to the overall conference theme of 'entrepreneurship as an engine of regional development'.

The venue for the 2008 conference was particularly appropriate since entrepreneurial activities of a technological and disruptive nature have always marked the growth and development of this spatial unit situated in inland Portugal. From the 18th century, through direct action by the Marquês de Pombal, the town of Covilhã became known internationally as the Manchester of Portugal, due to the high concentration of textile firms, especially those incorporating wool in their products, taking advantage of the 
natural resources available locally, namely sheep and pure water. In the 20th century, following successive implosions caused by the oil crises in the $70 \mathrm{~s}$, the textile industry entered a period of rapid decline, the role of an entrepreneurial university, created in 1986, being linked to the traditional textile cluster. In the final decade of the 20th century, this university reformed the economic, social and cultural environment of the Beira Interior region, through qualification of regional human capital and creation of university spin-offs in new areas of productive activity connected to services such as, multimedia, software, health and tourism. On the threshold of the 21 st century, the space is preparing for the rapid emergence of new productive specialisations, such as bioengineering, biotechnology and pharmacy, due to the growth and quality of the training supply in the area of health and the dynamism of two science and technology parks - Parkurbis (established) and UBI Medical (in preparation) - which involve the participation of various investors and promoters, notably the University of Beira Interior.

In fact, entrepreneurship has been a strategic driver in facilitating the adjustment to technological change and supporting competitiveness in terms of place. In this context, the role played by entrepreneurship deserves further attention by scholars and public policy makers. This is particularly critical, since there is a need to strengthen the institutional framework in terms of space, especially through establishment of formal and informal networks oriented to innovation and endogenous growth (Leitão and Baptista, 2009). Such a framework can be redesigned, according to the mapping of traditional and emerging activities of production and service supply. In a neo-Schumpeterian approach, this implies identifying groups of innovative activities geographically concentrated around a central driving force of innovation and regional development, that is, the entrepreneurial universities. The Covilhã region is one of many examples throughout Europe that illustrates the new 'glocal' role a region plays in a globalised economic landscape.

\section{Globalisation, entrepreneurship and the role of space}

A surprising phenomenon accompanying the wave of globalisation during the first decade of the 21 st century has been a shift in the comparative advantage of high-wage countries towards knowledge-based economic activity. An important implication of this shift in this comparative advantage is that much of the production and commercialisation of economic knowledge is less associated with multinational corporations and more with high-tech innovative regional clusters, such as Silicon Valley in California, the Cambridge area in the UK, the Montpellier area in France and potentially, the Covilhã area in Portugal. Only two decades ago, the conventional wisdom predicted that globalisation would destroy the region as a meaningful unit of economic analysis. Yet the obsession of policy-makers around the globe to 'create the next Silicon Valley' reveals the increased importance of geographic proximity and regional agglomerations as well as of the role of SMEs and entrepreneurial activity.

The purpose of this special issue is to explain the emergence of entrepreneurship and space, i.e., geographic localisation, as the two key organisational platforms because of and not in spite of a globalising economy. In other words, its purpose is to explain the relation between entrepreneurship and space which emerged after the advent of the ICT revolution and the resulting wave of globalisation.

The driving force underlying the emerging globalisation has been the ICT revolution: the advent of the microprocessor combined with its application in telecommunications 
has altered the economic meanings of national borders and distance (Audretsch et al., 2010). Globalisation would not have occurred to the degree that it has if the fundamental changes were restricted to the advent of the microprocessor and telecommunications. It took a political revolution in large parts of the world to reap the full benefits from these technological changes. The political counterpart of the technological revolution was the increase in democracy and concomitant stability in areas of the world that had previously been inaccessible (Audretsch and Thurik, 2001, 2010). The fall of the Berlin Wall in 1989 and subsequent downfall of communism in Eastern Europe and the former Soviet Union was a catalyst for stability and accessibility to parts of the world that had previously been inaccessible.

Globalisation has rendered the comparative advantage in traditional moderate technology industries incompatible with high wage levels. At the same time, the emerging comparative advantage that is compatible with high wage levels is based on innovative activity. More and more, these innovative activities happened in regions and clusters rather than in the laboratories of the multinational corporations. Thus, the regional response to globalisation has been the emergence of strategic policy measures not for firms, but for regions (Audretsch et al., 2007). As long as corporations were inextricably linked to their regional location by substantial sunk costs, such as capital investment, the competitiveness of a region was identical to the competitiveness of the corporations located in that region.

As globalisation has not only changed the degree to which the traditional economic factors of capital and labour are sunk, but also shifted the comparative advantage in the high-wage countries of North America and Europe toward knowledge-based economic activity, corporations have been forced to shift production to lower-cost locations. This has led to a delinking between the competitiveness of firms and regions. The advent of the strategic management of regions has been a response to the realisation that the strategic management of corporations includes a policy option not available to regions changing the production location. The realisation of this delinking and its consequences has led to renewed attention for the relationship between entrepreneurship and space. This is precisely the subject matter of the present special issue.

\section{Methodological issues for the study of entrepreneurship and space}

However, the study of strategic management of regions against the background of a knowledge-based and entrepreneurial economy still needs to address a number of methodological issues hampering process made in this field. In an 'entrepreneurial economy' (Audretsch, 1995, 2007), new firm formation is a strategic topic for the economic development of regions. Entrepreneurship research and education has been increasing steadily since the 1980s and the field has gained prominence and legitimacy. But while the number of entrepreneurship researchers is growing, entrepreneurship research has often been criticised for a lack of theoretical and methodological grounding (Cooper, 2003). However, recent literature attests to progress also in this field, visible through an increase of sophisticated models resulting in higher reliability and validity of research results (Chandler and Lyon, 2001). Despite these improvements, the generalisation of state-of-the-art research technology is still not widely visible and substantial methodological weaknesses remain (Mullen et al., 2009). The dimension of cultural differences regarding research designs and methods is another factor contributing to a certain heterogeneity - but also richness - of the field. A recent issue of 
Entrepreneurship Theory and Practice highlights the importance of grounding entrepreneurship research in its national context and reviews the state of the research field in four European countries compared to the USA (Welter and Lasch, 2008). European entrepreneurship research differs from US research in terms of methodological and thematic openness. Demonstrating the value of variety in the field, it also underlines that entrepreneurship research takes place in different national, methodological and thematic contexts (Welter and Lasch, 2008). However, international research represents a modest part of the empirical research in the area and deserves to be encouraged (Mullen et al., 2009). Despite recent progress and an increasing number of publications, more research is needed to appreciate the existence of different and contrasting environmental conditions for entrepreneurship (Ucbasaran et al., 2001). Similar trends observed in the field of entrepreneurship also apply to the theme labeled 'external environment' or 'entrepreneurship and space'. The question of how and why new ventures emerge in certain regions or socio-economic contexts has been addressed by a significant body of literature in the past, but the relationship between environmental conditions and new venture creation still lacks a comprehensive framework to study environmental conditions (Gnyawali and Fogel, 1994).

Even if an extensive body of literature on regional determinants of entrepreneurship exists, a number of gaps limit knowledge of this specific relationship. Contrasting results and methodological issues affect entrepreneurship research in this field, many questions by economic actors are unanswered and the valorisation of results for practice remains complex. Conducting entrepreneurship research in this theme encounters a number of significant barriers limiting the generalisation of results and the replication of research instruments or models in different contexts. Mullen et al. argue that "studies conducted in one (foreign) country remain 'domestic' unless the research design is from another country or in a different language and the intention is to compare results, or test or extend theory developed in a single country context. When a study is international, additional steps must be taken to ensure cross-national comparability" (2009, p.290). Analysing articles published between 2001 and 2008 in the leading small business-entrepreneurship journals, Mullen et al. observe that international research, with few exceptions, fails to control for variables stemming from national contextual differences between the nations under study (2009, p.290).

In many countries, the limited data available is another obstacle (Chandler and Lyon, 2001). Fritsch and Niese (2000), for example, illustrate those difficulties linked to limited data for measurement of entrepreneurship in Germany. On the contrary, the French statistical landscape offers an extraordinary richness of empirical data collected and administered by public statistical institutes (Lasch and Yami, 2008).

The use of different levels of analysis in studies is yet another constraint for the use of research results in academic study and practice. Davidson and Wiklund (2001) explore the levels of analysis in articles published in three leading journals in the field, and their results indicate that entrepreneurship research is dominated by micro-level analysis, mainly using the firm or the individual level of analysis. This micro-level dominance appears even to have increased over time, while the share of the aggregate level has declined [Davidson and Wiklund, (2001), p.84]. In addition, when exploring the relationship between entrepreneurship and the external environment, many studies analyse commonly used variables and proxies, but measure their impact on different aggregate levels (regions, administrative districts, agglomerations, labour market areas, 
etc.). Research designs depend very much on data availability for different aggregate levels. The countries cited above, Germany and France, for example, contrast widely in the quality of secondary statistics in general and the availability of empirical data for use in very specific aggregate levels (e.g., labour market area) or industry sector (e.g., four-digit ICIS codes).

Data availability can also explain why many studies explore the theme of 'entrepreneurship and space' as a 'snapshot' rather than in a longitudinal approach. Longitudinal research is especially needed to reduce common method variance, but those studies seem to be the exception rather than the rule [Chandler and Lyon, (2001), p.110]. The claims for more studies analysing one sector at a time or studies over time are not limited to the relationship between new ventures and the macro-environment. Schwartz and Teach (2000) stress that more studies using those research designs are also needed to analyse the relationship between entrepreneurial firms' strategy and performance.

\section{Regional determinants of entrepreneurship}

While the literature stresses the lack of a comprehensive framework to study environmental conditions of entrepreneurship, examination of research designs crystallises a number of key variables used to measure the influence of regional factors. Understanding the relationship between the regional socio-economic environment and the emergence of new ventures is an interdisciplinary effort in nature and entrepreneurship research draws greatly on economic geography literature and theory. In particular, localised economies and their influence on economic growth (Marshall, 1890; Arrow, 1962; Romer, 1986; Glaeser et al., 1992; Porter, 1990) have been used by entrepreneurship researchers in the past to explain the emergence of new ventures in regions or locations. New economic geography approaches focus on market forces to explain the spatial concentration or distribution of economic activities (Krugman, 1991). In the same line, the knowledge-based economy approach has also recently provided theoretical frameworks moving interaction between firms to the centre of discussion, analysing geographical proximity to external knowledge and innovation sources, formal and informal networks, knowledge spillovers, tacit knowledge, etc. Cluster theories analyse a variety of factors including market forces and local demand, to explain and describe the emergence of geographic concentrations of interconnected firms in one location (Porter, 1998). In summarising localisation economies here, we have to note that there are two viewpoints concerning the effect of industry and market structure on a location, in particular, industrial specialisation (concentration of firms in one industry) and diversity (large variety of industries). Entrepreneurship researchers do not limit their attention to the theories described briefly above but ground their studies on various other approaches, for example, endogenous growth theories. Endogenous growth theories address the role of regional human capital and innovation for economic growth and also provide a useful approach to complement understanding of the emergence of new ventures in one place (Romer, 1986).

Grounding their research designs on these theories and approaches, entrepreneurship researchers use a variety of variables to measure the regional influence on entrepreneurship and to formulate implications for research and practice.

Reviewing the literature regarding results and outcomes of empirical data analysis conducted in different countries, we observe how the local context ('region') impacts on 
entrepreneurship in many ways and on different levels. A strong local market demand for example appears to trigger entrepreneurship and to offer new opportunities for entrepreneurs; the attraction of the region (life quality) is also supposed to stimulate migration of population and to influence the choice of location for new ventures. Entrepreneurship is not only limited to growth regions, restructuration of former industrial core regions can also push former employees into self-employment or new ventures.

High unemployment in a region may stimulate entrepreneurship out of necessity, but may be seen as negative for the local business and entrepreneurship 'climate' and hamper entrepreneurs in locating and investing. A rich and prospering industry structure and employment opportunities offered in local firms may provide good career possibilities and so reduce the level of entrepreneurship. Local culture and entrepreneurial 'climate' may produce positive role models for future entrepreneurs.

Many start-ups are founded in the proximity of the entrepreneurs' residence (Keeble et al., 1993) revealing the importance of 'endogenous potential' and putting the demographic structure of the population in the forefront of interest. The literature emphasises a strong link between education and entrepreneurship. Social and personal networks also appear to be of major importance (Greve and Salaff, 2003). Interaction, cooperation and networking offer possibilities to draw on external knowledge sources. Networking possibilities, face-to-face contacts, 'implicit' knowledge and highly specialised information are considered as relevant regional factors for entrepreneurship (Saxenian, 1994).

Universities and research facilities are an important source of external knowledge that is not only limited to innovative firms (Meyer-Krahmer and Schmoch, 1998; Bade and Nerlinger, 2000). Universities also play an important role as a breeding ground for future entrepreneurs (academic or scientific spin-offs).

Market size and business infrastructure are considered as advantages for start-ups in urban areas with high population density (Brüderl et al., 1996). Entrepreneurs benefit from positive agglomeration externalities to reduce their transaction costs (a specialised job market, highly developed infrastructure, regional networks, knowledge spillovers, etc.). But when certain levels of density are attained, diseconomies of location may turn advantages into barriers.

Local firm size structures also influence the level of entrepreneurship. The firm where the entrepreneur accumulated his experience can be relevant for the managerial and entrepreneurial learning process. The literature stresses that employees in small firms obtain more opportunities to gain entrepreneurial and managerial knowledge compared to those in large firms with a higher division of labour (Greenan, 1994). However, concerning unemployment, contrasting results prevail in the literature ['seedbed effect' for entrepreneurship in manufacturing and industry vs. large firm effect on service ventures (Reynolds et al., 1994)].

The diversification or concentration of the local industry structure is also highlighted as a key determinant for entrepreneurship in certain sectors (Fritsch and Niese, 2000). High diversification is supposed to trigger entrepreneurship as potential founders and clients are split over a great number of branches. Sector concentration (presence of similar activities to those of new firms) is supposed to be especially relevant for innovative or high-tech entrepreneurship (localisation economies). Innovation and synergy are considered as important factors for regional development and competitiveness (Ritsilä, 1999) and reflect proximity effects or interaction between firms 
in the local context (Collinson and Gregson, 2003). Proximity is often related to good opportunities for integration in the local network.

These are only a few examples to illustrate the complex relationship between entrepreneurship and space. This special issue brings together major contributions presented at the 2008 RENT Conference in Portugal and intends to contribute to advancing knowledge and to outlining future research directions for entrepreneurship studies focusing on the relationship between new venturing and space.

\section{The present special issue}

The first three articles in this special issue focus on the role played by innovation on the performance of SMEs (Serrasqueiro; Clausen; Faria and Mendonça). Thereafter, the fourth article (Folkeringa, van Stel, Suddle and Tan) reveals industry differences through analysis of business dynamics reflecting competition among incumbent firms. The fifth article (Rønning) tests the network success hypothesis with a sample of Norwegian farm households, by analysing the compensation hypothesis, which states that social capital compensates entrepreneurs for lack of human capital or financial capital. The sixth article (Sousa, Fontes and Videira) proposes a methodology that enables a comprehensive investigation of the networking behaviour of Portuguese biotech entrepreneurs in their search for resources for firm formation and early development. The seventh article (Battisti and Peter) demonstrates the important role played by the owner-manager's perceptions as a determinant of collaboration by SMEs in the New Zealand context.

The first article (Serrasqueiro) focuses on growth of Portuguese SMEs, by using panel data models. The influence of age and size of SMEs is analysed, by using two research sub-samples corresponding to low-age, low-size Portuguese SMEs and high-age, high-size Portuguese SMEs. The main results show that greater size is more important for increased long-term debt for high-age, high-size SMEs than for low-age, low-size SMEs. This econometric approach applied to the Portuguese space reveals that recognition of growth opportunities by creditors is critical for sustaining SME growth, allowing them to diversify activities and products through innovation.

The second article (Clausen) revisits the Schumpeter hypothesis, which states that larger firms are more innovative than smaller firms, in the context of open and closed innovation. The author finds empirical support for a more evolutionary interpretation of the Schumpeter hypothesis, by highlighting also that in the open innovation context, there are much stronger links between start-up firms, external research and development $(R \& D)$ and radical innovation.

While the first two articles explore determinants of SME performance, revealing the importance of innovative activities for the growth of start-ups located in Portugal, Norway and Sweden, the third article (Faria and Mendonça) analyses the relationship between innovation and firm performance, distinguishing product and process innovation. The authors find a lagged impact of innovation activities on the performance of new Portuguese small firms, thus leading to the conclusion that innovation activities may be a source of competitive advantage, especially for new firms.

The fourth article (Folkeringa, van Stel, Suddle and Tan) analyses the business dynamics reflecting competition among incumbent firms, for assessing the industry's level of competitiveness and economic performance of firms located in the Netherlands. For this purpose, the authors compute mobility indices for 16 industries and compare them across the sectors. The communication, hotel and restaurant sectors displayed the 
highest mobility rates, while the chemical industry was found to be the least mobile industry. The authors provided several possible explanations for these industry differences, including scale, technology and market structure.

The fifth article (Rønning) analyses the way social capital can compensate entrepreneurs for lack of human capital or financial capital, in the Norwegian context. By using a logistic regression approach applied to farm households, the author states that farming experience and partly education diminish the positive associations between social capital variables and entrepreneurial activity.

Coming back to the Portuguese regional space, the sixth article (Sousa, Fontes and Videira) analyses the influence of entrepreneurs' social networks on opportunity identification and on early access to and mobilisation of resources, in a science-based field. The methodology proposed is applied to a sub-set of Portuguese molecular biology firms. The authors explore the process of network building and network mobilisation, as well as the contribution of different types of networks to the entrepreneurial process.

The last article (Battisti and Peter), from a social capital approach, reveals that exploitation of the cognitive characteristics of SME owners/managers can foster SME collaboration. The authors analyse the differences between small firms that engage in collaboration and those that do not, by examining SME owner/managers' perceptions of the barriers and benefits of collaboration. By using a discriminate analysis applied to a sample of small firms in New Zealand, the authors find that non-collaborating SMEs see collaboration as a means of compensating for their resource constraints by gaining access to labour and capital. Nevertheless, owner-managers of collaborating SMEs seem to be able to exploit opportunities beyond available resources.

\section{References}

Arrow, K. (1962) 'Economic welfare and the allocation of resources for innovation', in Nelson, R. (Ed.): The Rate and Direction of Inventive Activity, pp.609-626, Princeton University Press, Princeton, NJ.

Audretsch, D. (1995) Innovation and Industry Evolution, MIT Press, Cambridge, MA.

Audretsch, D. (2007) The Entrepreneurial Society, Oxford University Press, Oxford, UK.

Audretsch, D. and Thurik, R. (2001) 'What is new about the new economy: sources of growth in the managed and entrepreneurial economies', Industrial and Corporate Change, Vol. 10, No. 1, pp.267-315.

Audretsch, D. and Thurik, R. (2010) 'From the managed to the entrepreneurial economy: ten years after', Report ERS-2010-xxx-ORG, Erasmus Research Institute of Management, Erasmus University Rotterdam, forthcoming.

Audretsch, D., Grilo, I. and Thurik, R. (2010) 'Globalization, entrepreneurship and the region', in Fritch, M. (Ed.): Elgar Handbook of Research on Entrepreneurship and Regional Development, Edward Elgar Publishing Limited, Cheltenham, UK and Northampton, MA, USA, forthcoming.

Audretsch, D., Grilo, I. and Thurik, R. (Eds.) (2007) The Handbook of Research on Entrepreneurship Policy, Edward Elgar Publishing Limited, Cheltenham, UK and Northampton, MA, USA.

Bade, F-J. and Nerlinger, E. (2000) 'The spatial distribution of new technology-based firms: empirical results for West-Germany', Papers of Regional Science, Vol. 79, No. 2, pp.155-176.

Brüderl, J., Preisendörfer, P. and Ziegler, R. (1996) Der Erfolg neu gegründeter Betriebe: eine empirische Studie zu den Chancen und Risiken von Unternehmensgründungen', No. 140, Betriebswirtschaftliche Schriften, Berlin.

Chandler, G. and Lyon, D. (2001) 'Issues of research design and construct measurement in entrepreneurship research: the past decade', Entrepreneurship Theory and Practice, Vol. 25, No. 4, pp.101-113. 
Collinson, S. and Gregson, G. (2003) 'Knowledge networks for new technology-based firms: an international comparison of local entrepreneurship promotion', R\&D Management, Vol. 33, No. 2, pp.189-208.

Cooper, A. (2003) 'Entrepreneurship: the past, the present, the future', in Acs, Z. and Audretsch, D. (Eds.): Handbook of Entrepreneurship Research, pp.21-34, Kluwer Academic Publishers, Boston/Dordrecht.

Davidson, P. and Wiklund, J. (2001) 'Levels of analysis in entrepreneurship research: current research practice and suggestions for the future', Entrepreneurship Theory and Practice, Vol. 25, No. 4, pp.81-99.

Fritsch, M. and Niese, M. (2000) 'Der einfluss der branchenstruktur auf das gründungsgeschehen eine analyse für die westdeutschen raumordnungsregionen 1983-1997', Geographische Zeitschrift, Vol. 88, Nos. 3-4, pp.234-250.

Glaeser, E., Kallal, H., Scheinkman, J. and Shleifer, A. (1992) 'Growth of cities', Journal of Political Economy, Vol. 100, No. 6, pp.1126-1152.

Gnyawali, D. and Fogel, D. (1994) 'Environments for entrepreneurship development: key dimensions and research implications', Entrepreneurship Theory and Practice, Vol. 18, No. 4, pp.43-62.

Greenan, N. (1994) 'L'organisation du travail dans les PMI se distingue-t-elle de celle des grandes entreprises ?', Economie et Statistiques, Nos. 271-272, pp.87-103.

Greve, A. and Salaff, J. (2003) 'Social networks and entrepreneurship', Entrepreneurship, Theory and Practice, Vol. 28, No. 1, pp.1-22.

Keeble, D., Walker, S. and Robson, M. (1993) 'New firm formation and small business growth in the United Kingdom: spatial and temporal variations and determinants', Research Series No. 15, Employment Department, London.

Krugman, P. (1991) 'Increasing returns and economic geography', Journal of Political Economy, Vol. 99, No. 3, pp.483-499.

Lasch, F. and Yami, S. (2008) 'The nature and focus of entrepreneurship research in France over the last decade: a French touch?', Entrepreneurship Theory and Practice, Vol. 32, No. 2, pp.339-360.

Leitão, J. and Baptista, R. (Eds.) (2009) 'Public policies for fostering entrepreneurship: a European perspective', Series: International Studies in Entrepreneurship, Vol. 22, Springer Academic Publishers, New York.

Marshall, A. (1890) Principles of Economics, Reprint, Prometheus Books, Amherst, NY.

Meyer-Krahmer, F. and Schmoch, U. (1998) 'Science-based technologies: university-industry interactions in four fields', Research Policy, Vol. 27, No. 8, pp.835-851.

Mullen, M., Desislava, G. and Doney, P. (2009) 'Research methods in the leading small business-entrepreneurship journals: a critical review with recommendations for future research', Journal of Small Business Management, Vol. 47, No. 3, pp.287-307.

Porter, M. (1990) The Comparative Advantage of Nations, The Free Press, New York.

Porter, M. (1998) 'Clusters and the new economics of competition', Harvard Business Review, Vol. 76, No. 6, pp.77-90.

Reynolds, P., Storey, D. and Westhead, P. (1994) 'Cross-national comparisons of the variation in new firm formation rates', Regional Studies, Vol. 28, No. 4, pp.443-456.

Ritsilä, J. (1999) 'Regional differences in environments for enterprises', Entrepreneurship and Regional Development, Vol. 11, No. 3, pp.187-202.

Romer, P. (1986) 'Increasing returns and long-run growth', Journal of Political Economy, Vol. 94, No. 5 , pp. $1002-1037$.

Saxenian, A. (1994) 'Regional networks and the resurgence of Silicon Valley', Californian Management Review, Vol. 33, No. 1, pp.89-117.

Schwartz, R. and Teach, R. (2000) 'Entrepreneurship research: an empirical perspective. Research note', Entrepreneurship Theory and Practice, Vol. 24, No. 3, pp.77-81.

Ucbasaran, D. Westhead, P. and Wright, M. (2001) 'The focus of entrepreneurial research: contextual and process issues', Entrepreneurship Theory and Practice, Vol. 25, No. 5, pp. $57-80$

Welter, F. and Lasch, F. (2008) 'Entrepreneurship research in Europe: taking stock and looking forward', Entrepreneurship Theory and Practice, Vol. 32, No. 2, pp.241-248. 